JPdK Volume 2 No 2 Tahun 2020 Halaman 183-187 JURNAL PENDIDIKAN dan KONSELING

Research \& Learning in Primary Education UNIIVERSITAS

\title{
Peningkatan Keterampilan Membaca Pemahaman Siswa Dengan Menggunakan Model Scanning Pada Siswa Sekolah Dasar
}

\author{
Ani Mahyuni' ${ }^{1}$ Nurmalina $^{2}$, Masrul $^{3}$ \\ Program Pendidikan Guru Sekolah Dasar \\ Fakultas Ilmu Pendidikan \\ Universitas Pahlawan Tuanku Tambusai \\ Email :animahyuni111@gmail.com
}

\begin{abstract}
Abstrak
Penelitian ini di latar belakangi oleh rendahnya keterampilan membaca pemahaman siswa pada pembelajaran tematik di kelas V Mi Al-Falah Teratak. Salah satu solusi untuk mengatasi masalah ini adalah dengan menggunakan model scanning. Penelitian ini bertujuan untuk mengetahui peningkatan keterampilan membaca pemahaman siswa dengan menggunakan model scanning pada siswa kelas V MI Al-Falah Teratak. Metode penelitian ini adalah Penelitian Tindakan Kelas (PTK) yang dilaksanakan dalam dua siklus. Subjek penelitian ini siswa kelas $\mathrm{V}$ yang berjumlah 10 orang, dengan jumlah laki-laki 4 orang, dan siswa perempuan berjumlah 6 orang siswa. Teknik pengumpulan berupa dokumentasi, observasi, dan tes. Hasil penelitian ini dapat disimpulkan bahwa model scanning dapat meningkatkan keterampilan membaca pemahaman siswa pada kelas V MI Al-Falah Teratak. Pada siklus I hasil keterampilan membaca pemahaman siswa tergolong kurang dengan persentase $50 \%$. Selanjutnya pada siklus II dengan persentase 90\% dengan katagori sangat baik. Dari 10 orang siswa hanya 9 orang siswa yang tuntas dengan ketuntasan klasikal 90\%. Dengan demikian dapat disimpulkan bahwa dengan menggunakan model scanning dapat meningkatkan keterampilan membaca pemahaman siswa kelas V MI AlFalah Teratak Tahun ajaran 2020/2021.
\end{abstract}

Kata Kunci: Keterampilan membaca pemahaman menggunakan model scanning

\begin{abstract}
This research was motivated by the low reading comprehension skills of students in thematic learning in class $\mathrm{V}$ Mi Al-Falah Teratak. One solution to solve this problem is to use a scanning model. This study aims to determine the improvement of students' reading comprehension skills by using the scanning model in grade V students of MI Al-Falah Teratak. This research method is Classroom Action Research (PTK) which is carried out in two cycles. The subjects of this study were 10 grade V students, 4 male students and 6 female students. Collection techniques in the form of documentation, observation, and tests. The results of this study can be concluded that the scanning model can improve reading skills of students in class V MI Al-Falah Teratak. In the first cycle the results of students' reading comprehension skills were classified as low with a percentage of $50 \%$. Furthermore, in cycle II with a percentage of $90 \%$ in the very good category. Of the 10 students, only 9 students completed with $90 \%$ classical completeness. Thus it can be concluded that using the scanning model can improve reading comprehension skills of grade V students at MI Al-Falah Teratak for the 2020/2021 school year.
\end{abstract}

Keywords: Reading comprehension skills using a scanning model

\section{PENDAHULUAN}

Pembelajaran Bahasa Indonesia merupakan mata pelajaran mendasar yang sudah diajarkan sejak SD, SMP, SMA/SMK sampai dengan Perguruan Tinggi. Bahasa Indonesia mempunyai peran penting dalam proses pembelajaran. Kurikulum Bahasa Indonesia di SD mempunyai karakteristik, menggunakan pendekatan komunikatif keterampilan proses, tematis integratif, dan lintas kurikulum. Mengutamakan variasi, kealamian, kebermaknaan fleksibelitas, penggunaan metode, memberi peluang untuk menggunakan berbagai sumber belajar Djuanda (2006: 53).

Pedoman pembelajaran Bahasa Indonesia di sekolah dasar mengacu pada Undang-Undang Nomor 20 Tahun 2003 tentang Sistem Pendidikan Nasional dan Peraturan Menteri Pendidikan Nasional Nomor 22 Tahun 2006 tentang standar isi, secara garis besar pembelajaran Bahasa Indonesia di sekolah dasar diarahkan untuk meningkatkan kemampuan siswa untuk berkomunikasi dalam Bahasa Indonesia dengan baik dan benar, baik 
secara lisan maupun tulis, serta menumbuhkan apresiasi terhadap hasil karya kesastraan manusia indonesia. Ruang lingkup mata pelajaran Bahasa Indonesia di sekolah dasar mencakup komponen kemampuan berbahasa dan yang meliputi aspek mendengarkan, berbicara, membaca, dan menulis.

Keterampilan berbahasa di sekolah dasar mencakup empat keterampilan berbahasa yaitu keterampilan menyimak, berbicara, membaca, dan menulis. Membaca adalah kunci ke arah gudang ilmu, pintar membaca dan banyak membaca maka yang bersangkutan banyak mendapatkan ilmu pengetahuan dan pengalaman. Kaya ilmu dan pengetahuan pasti mudah berbicara atau menulis tentang ilmu dan pengetahuan yang telah dimiliki. Kegiatan membaca merupakan suatu proses mengolah bacaan secara kritis kreatif dengan tujuan untuk memperoleh pemahaman yang bersifat menyeluruh dan mendalam tentang isi bacaan.

Salah satu keterampilan berbahasa yang harus dikuasai siswa adalah keterampilan membaca, karena keterampilan membaca merupakan bagian terpadu dari keterampilan berbahasa. Rahim, (2007: 1) mengemukakan bahwa kemampuan membaca merupakan sesuatu yang vital dalam suatu masyarakat terpelajar. Membaca semakin penting dalam kehidupan masyarakat yang semakin kompleks, karena setiap aspek kehidupan melibatkan kegiatan membaca.

Berdasarkan observasi yang membuat siswa semakin kurang berminat dalam mengikuti kegiatan pembelajaran bahasa Indonesia. Dalam hal ini siswa harus diminta atau diperintah terlebih dalu untuk melakukan kegiatan membaca. Kendala lainnya yaitu siswa hanya sekedar membaca tanpa memcari tahu maksud atau inti dari isi teks yang mereka baca. Saat membaca siswa juga kurang memahami isi bacaan karena hanya sebatas membaca dari awal hingga akhir, sehingga kemampuan membaca pemahaman siswa masih kurang dari KKM.

Penggunaan waktu dalam pembelajaran menjadi kurang afektif karena banyak siswa yang masih binggung dalam memahami suatu bacaan. Dalam hal ini siswa sibuk bertanya dengan siswa lainnya. Dengan demikian banyak waktu yang terbuang sia-sia.

Kendala lain yang menjadi perhatian siswa kurang mampu dalam mengajukan atau membuat pertayaan, dan sulit menjelaskan atau menceritakan isi bacaan. Meski disadari bahwa hal ini disebabkan kurangnya latihan dan hal itu pula yang mempengaruhi tingkat kemampuan membaca pemahaman siswa. Membaca tidak hanya sekedar melafalkan huruf, namun lebih kepada memahami pesan yang disampaikan oleh tulisan yang ditangkap oleh indra penglihatan. Setiap bacaan yang kita baca, memiliki informasi dan peran tersendiri, pesan tersebut akan sampai apabila pembaca benar - benar dalam memahami isi bacaan merupakan akhir dari membaca, tetapi kenyataan yang ada belum semua siswa dapat mencapai tujuan tersebut. Banyak siswa yang dapat membaca lancar suatu bahan bacaan tetapi tidak memahami isi bahan bacaan tersebut.

Tujuan dari membaca adalah memahami isi bacaan, tetapi kenyataan yang ada belum semua siswa dapat mencapai tujuan tersebut. Banyak anak yang dapat membaca lancar suatu bahan bacaan tetapi tidak memahami isi bacaan. Membaca pemahaman adalah kemampuan seseorang memahami isi dan makna dari sebuah bacaan. berdasarkan wawancara pada tanggal 30 Maret 2020 dengan guru kelas V diMi Al-Falah Teratak, maka ditemukan beberapa permasalahan yaitu sebagai berikut: 1) siswa kesulitan menemukan kalimat penting dari teks cerita yang dibaca, 2) siswa kesulitan dalam menemukan ide pokok dari teks cerita yang dibaca, 3) siswa tidak ada bertanya kepada guru tentang isi teks bacaan yang kurang dipahaminya.

Berdasarkan permasalahan, perlu pemilihan model pembelajaran yang tepat untuk mengajarkan kemampuan membaca pemahaman siswa pada mata pelajaran bahasa Indonesia. Salah satu usaha yang dapat dilakukan adalah menerapkan model pembelajaran yang bertujuan agar siswa lebih aktif, lebih antusias, dan bersemangat untuk mengerjakan latihan serta mempunyai rasa tanggung jawab dengan tugas (Rusdial marta, 2017: 36).Untuk meningkatkan kemampuan mambaca pemahaman siswa dalam proses pembelajaran Bahasa Indonesia adalah dengan menggunakan model pembelajaran scanning (memindai). Model pembelajaran scanning merupakan model dalam pembelajaran membaca yang dapat dijadikan sebagai alat penunjang pembelajaran untuk membantu kelancaran efektifitas dan efisiensi pencapaian tujuan pembelajaran yang ingin dicapai. Penerapan model scanning dalam pembelajaran keterampilan membaca memindai, akan dapat memotivasi siswa dalam proses pembelajaran. Dengan model scanning siswa diharapkan akan lebih mudah dalam menemukan informasi. Karena ketika siswa membaca memindai, dia akan melampaui banyak kata tanpa harus membaca secara keseluruhan (Rahim, 2009:52).

Berdasarkan latar belakang seperti yang dikemukakan, penulis tertarik untuk melakukan kegiatan penelitian dengan judul: "Peningkatan Keterampilan Membaca Pemahaman Siswa dengan Menggunakan Model Scanning pada Siswa Kelas V MI Al-FalahTeratak".

\section{METODOLOGI PENELITIAN}

Subjek Penelitian Tindakan Kelas (PTK) adalah siswa kelas V MI Al-FalahTeratak yang berjumlah 10 orang siswa, yang terdiri dari 6 orang siswa perempuan dan 4 orang siswa laki-laki. Penelitian mengambil subjek penelitian di kelas V 
karena permasalahan membaca pemahaman merupakan permasalahan yang terdapat pada siswa pada kelas VMI Al-FalahTeratak. Adapun yang terlibat dalam penelitian ini adalah:

1. Peneliti sebagai guru praktik pada kelas

2. Observer 1 yaitu guru kelas MI Al-Falah Teratak dan observer II yaitu teman sejawat.

Metode yang digunakan dalam penelitian ini adalah Penelitian Tindakan Kelas (PTK) Jenis penelitian yang akan dilakukan adalah Penelitian Tindakan Kelas (PTK). Menurut Kunandar (2008:6) PTK adalah penelitian tindakan yang dilakukan dengan tujuan dengan memperbaiki mutu praktik pembelajaran di kelas. Model penelitian secara garis besar terdapat empat tahapan yaitu perencanaan, pelaksanaan, pengamatan, dan refleksi.

\section{A. Teknik Pengumpulan Data}

Data penelitian mengenai peningkatan keterampilan membaca pemahaman siswa di peroleh dengan cara teknik dokumentasi juga diperlukan untuk melampirkan foto pada saat pembelajaran berlangsung. melalui:

Adapun data dalam penelitian ini di peroleh

\section{Observasi :}

Pemerolehan data dalam penelitian ini salah satunya adalah dari hasil observasi. Observasi adalah cara menghimpun bahan-bahan keterangan yang dilakukan dengan mengadakan pengamatan dan pencatatan secara sistematis terhadap fenomenafenomena yang sedang dijadikan sasaran pengamatan. Observasi dilakukan dengan pengamatan langsung terhadap subjek penelitian, untuk melakukan pengamatan penulis menyiapkan instrumen berupa chek list $(\sqrt{ })$ (Wida rianti, 2016: 38). Observasi digunakan untuk menilai tingkah laku individu atau proses terjadinya suatu kegiatan yang dapat diamati, baik dalam situasi yang sebenarnya maupun dalam situasi buatan.

\section{B. Teknik Analisis Data}

1. Data kuantitatif data yang diperoleh berdasarkan tes yang diberikan kepada siswa setiap akhir pelajaran. Analisis data kuantitatif dilakukan dengan melihat ketuntasan belajar setelah menjawab soal tes yang diberikan, baik secara individu maupun secara klasikal. Teknik kuantitatif adalah teknik analisis data yang berupa angka.

a. Pengolahan presentasi ketuntasan belajar

Kelas dikatakan sudah tuntas secara klasikal jika telah mencapai $85 \%$ dari seluruh siswa memperoleh nilai Kriteria Ketuntasan Minimal (KKM)" menurut Depdiknas (2006). Dengan pembelajaran perlu diadakanya perhitungan presetase jumlah siswa yang tuntas atau telah memenuhi KKM pada mata pelajaran bahasa Indonesia yaitu 70. Pengolahan data ketuntasan secara klasikal dihitung dengan menggunakan rumus :

$\mathrm{P}=\Sigma$ SiswaTuntasBelajar X100\% ¿siswa

b. Data kualitatif data kualitatif merupakan data yang berupa informasi berbentuk kalimat yang memberikan gambaran tentang ekspresi peserta didik berkaitan dengan tingkat pemahaman terhadap suatu mata pelajaran (kognitif) pandangan atau sikap (afektif), aktivitas peserta didik mengikuti pelajaran, perhatian, antusias dalam belajar, kepercayaan diri, motivasi belajar, dapat di analisis secara kualitatif (iskandar, 2011:75).

\section{HASIL PENELITIAN DAN PEMBAHASAN}

Deskripsi Pratindakan dilakukan Peneliti menganalisis data keterampilan membaca pemahaman dengan tujuan untuk mengetahui peningkatan hasil keterampilan membaca pemahaman siswa. Berdasarkan data hasil belajar anak pada keterampilan membaca pemahaman tanpa mengunakan model scanning permasalahan yang ditemukan pada kelas V MI Al-Falah Teratak antara lain: Siswa masih malu dan tidak berani untuk maju ke depan kelas. Siswa pasif saat pelajaran, beberapa siswa hanya mendengarkan tanpa bertanya. Rendahnya keterampilan membaca pemahaman siswa mengakibatkan keterampilan membaca pemahaman masih rendah. Berdasarkan hasil analisis observasi dan wawancara dengan guru kelas yang peneliti lakukan, hal itulah yang dijadikan sebagai dasar dan acuan peneliti untuk melakukan penelitian pada pembelajaran mengenai keterampilan membaca pemahaman siswa kelas V MI Al-Falah Teratak. Agar keterampilan membaca pemahaman siswa dapat terlaksana dengan baik. Salah satu upaya yang dilakukan oleh guru dalam proses pembelajaran mengenai keterampilan membaca pemahaman siswa agar siswa lebih aktif dan kreatif khususnya dalam peningkatan keterampilan membaca pemahaman siswa yaitu dengan menggunakan model scanning yang diharapkan dapat meningkatkan keterampilan membaca pemahaman siswa kelas V MI Al-Falah Teratak.

Berdasarkan hasil yang diperoleh data nilai keterampilan membaca pemahaman dari guru kelas V MI Al-Falah Teratak. Peneliti menganalisis data tersebut dengan kategori yang ditentukan oleh peneliti yaitu kategori cukup dengan nilai minimal 70 , dari 10 siswa hanya 2 siswa (20\%) yang telah memenuhi kategori yang ditentukan oleh peneliti dan siswa yang tidak memenuhi kategori yang ditentukan oleh peneliti sebanyak 8 siswa (80\%).

Deskripsi hasil tindakan tiap siklus di lakukan empat kali pertemuan yang mana siklus I dua kali pertemuan dan siklus II dua kali petemuan. Pada siklus I terdapat tahapan yang perlu peneliti lakukan yaitu tahap perencanaan, pelaksanaan, observasi dan refleksi. Berdasarkan data yang diperoleh kemampuan siswa dalam membaca pemahaman pada siklus I pertemuan I dari jumlah 10 siswa yang 
mencapai kategori yang ditentukan peneliti yaitu kategori cukup dengan nilai minimal 70 berjumlah 3 siswa (30\%). Siswa yang tidak mencapai kategori yang sudah ditentukan berjumlah 7 siswa (70\%). Sedangkan pada siklus I pertemuan II dari jumlah 10 siswa mencapai kategori yang telah ditentukan peneliti yaitu kategori cukup dengan nilai minimal 70 berjumlah 5 siswa $(50 \%)$, dan siswa yang tidak mencapai kategori yang telah ditentukan oleh peneliti berjumlah 5 siswa (50\%). Dengan menggunakan model scanning, dapat dilihat bahwa nilai keterampilan membaca pemahaman siswa kelas V Mi Al-Falah Teratak pada tindakan siklus I mengalami peningkatan apabila dibandingkan dengan nilai pratindakan. Peningkatan keterampilan membaca pemahaman pada siklus I sebesar $50 \%$ secara klasikal sedangkan nilai pratindakan siswa hanya 20\% secara klasikal.

Deskripsi Hasil Tindakan Siklus II dalam penelitian ini terdiri dari dua pertemuan, masingmasing pertemuan berlangsung kurang lebih selama 70 menit (2x35 menit) atau 2 jam pelajaran. Berdasarkan data yang diperoleh kemampuan siswa dalam membaca pemahaman pada siklus II pertemuan I dari jumlah 10 siswa yang mencapai kategori yang ditentukan peneliti yaitu kategori cukup dengan nilai minimal 70 berjumlah 7 siswa (70\%) dengan kategori cukup. Siswa yang tidak mencapai kategori yang sudah ditentukan berjumlah 3siswa $(30 \%)$ dengan kategori kurang. Sedangkan pada siklus II pertemuan II, dari jumlah 10 siswa mencapai kategori yang telah ditentukan peneliti yaitu kategori cukup dengan nilai minimal 70 berjumlah 9siswa (90\%) dengan kategori sangat baik,. Sedangkan siswa yang tidak mencapai kategori yang telah ditentukan oleh peneliti berjumlah 1 siswa (10\%) dengan kategori kurang. Dengan menggunakan media teks cerita, dapat dilihat bahwa nilai keterampilan berbicara siswa kelas V MI Al-Falah Teratak pada tindakan siklus II mengalami peningkatan apabila dibandingkan dengan nilai pada siklus I. Peningkatan keterampilan Membaca Pemahaman pada siklus II sebesar $90 \%$ secara klasikal. Jadi hasil keterampilan Membaca Pemahaman siswa pada siklus II telah mencapai ketuntasan klasikal.

Berdasarkan deskripsi tersebut dapat disimpulkan bahwa keterampilan membaca pemahaman siswa mengalami peningkatan dengan menggunakan media teks cerita. Jadi, hasil analisis ini mendukung hipotesis tindakan yang diajukan yaitu " Jika penggunaan teks cerita diterapkan maka dapat meningkatkan keterampilan membaca pemahaman siswa kelas V MI Al-Falah Teratak".

\section{SIMPULAN}

Berdasarkan hasil penelitian yang telah dilaksanakan selama dua siklus dengan menggunakan model Scanning untuk peningkatan keterampilan membaca pemahaman siswa pada siswa kelas V MI Al-Falah Teratak pada semester ganjil 2020/2021, dapat ditingkatkan dengan menggunakan model scanning.
Melalui pembelajaran dengan menggunakan model scanning siswa lebih mudah untuk mengembangkan keterampilan membaca pemahaman siswa meningkat. Peningkatan tersebut dapat dilihat dari adanya peningkatan persentase dari tahap pratindakan dan setelah dilakukan tindakan kelas. Hasil observasi pada tahap pratindakan siswa yang kategori cukup hanya 3 siswa dan yang baik 2 siswa. Setelah dilakukan tindakan siklus I dan II jumlah siswa yang sesuai harapan berjumlah 9 siswa meningkat lebih baik lagi dan masuk kategori sangat baik.

Adapun hasil keterampilan membaca pemahaman siswa pada kelas V MI Al-Falah Teratak pada siklus I mencapai ketuntasan klasikal yaitu $50 \%$ dengan 5 orang siswa yang tuntas. Kemudian pada siklus II ketuntasan meningkat menjadi $90 \%$ dengan siswa yang tuntas 9 orang siswa dan jumlah siswa yang tidak tuntas 1 orang. Dari hasil setiap siklus dapat diperoleh keismpulan bahwa untuk peningkatan keterampilan membaca pemahaman siswa pada siswa kelas V MI Al-Falah Teratak dapat mengunakan model scanning dalam proses pembelajaran siswa.

\section{A. Implikasi}

Implikasi pelaksanaan pembelajaran tematik tema 2 subtema 2 siswa MI Al-FalahTeratak adalah peningkatan keterampilan membaca pemahaman siswa menggunakan model scanning. Maka penelitian ini berdampak sebagai;

\section{Implikasi Teoritis}

Implikasi teoritis dari penelitian ini yaitu dengan adanya implementasi penggunaan model scanning, dapat meningkatkan keterampilan membaca pemahaman siswa. Dengan menggunakan model scanning, pembelajaran siswa menjadi menyenangkan sehingga siswa semangat untuk belajar dan juga dapat membantu siswa agar lebih mudah untuk memahami teks cerita.

\section{Implikasi Praktik}

Hasil penelitian yang digunakan sebagai masukan untuk sekolah, guru dan calon guru untuk membenahi diri dan meningkatkan keterampilan membaca pemahaman sehubung dengan penggunaan model scanning untuk keterampilan membaca pemahaman. Pembelajaran dengan menggunakan model scanning dapat dijadikan sebagai bahan acuan untuk mengadakan penelitian selanjutnya dari sudut permasalahan yang berbeda.

\section{DAFTAR PUSTAKA}

Depdiknas. 2006. Permendiknas No 22 Tahun 2006 TentangStandar Isi. Jakarta: Depdiknas.

Djuanda, D. Dkk. 2006. Pembinaan Dan Pengembangan Pembelajaran Bahasa Dan Sastra Indonesia. Bandung. UPI Press. $\begin{array}{ccc}\text { Kunandar. } & 2016 . \text { Langkah Mudah Penelitian } \\ \text { Tindakan Kelas } & \text { Sebangai }\end{array}$ Pengembang Profesi Guru. Jakarta: Raja Grafindo Persada.

Rahim, 2007. Pengajaran membaca di sekolah 
dasar. Jakarta: Bumi Aksara.

2009. Pengajaran membaca di sekolah dasar. Jakarta: Bumi Aksara.

Rusdial marta. 2017. Peningkatan Hasil Belajar IPS dengan Menggunakan Model Word Square Sekolah Dasar. Lembaran Ilmu Kependidikan. Volume 46.
Nomor 1.

Wida rianti. 2016. Meningkatkan Kemampuan Mengenal Lambang Bilangan Melalui Permainan Tata Angka pada Anak Usia Dini. Jurnal PAUD. Volume 2 Nomor 2. Halaman $36-42$ 